\title{
Improvement of Mathematical Communication Skills for Students DIII Mechanical Engineering with Think Pair Share Method: A Case of Indonesia
}

\author{
M. Taufik Qurohman*), Syaefani Arif Romadhon, Muchamad Sobri Sungkar \\ Politeknik Harapan Bersama, Tegal, Jawa Tengah
}

\begin{abstract}
2021 Think Pair Share (TPS) based on Mathematical Good communication is a Revised: August 04,2021 good thing expected related to the solutions students in college to improve Accepted: September 13, 2021 the attractiveness and troubleshooting ability for mechanical engineering students in Indonesia. Research on this occasion is CAR (Class Action Research). Results of the study are: (1) student interest before and after learning underwent a change in the first cycle that $53 \%$ experienced an increase in $97 \%$ at cycle stage II, (2) there was an increase for a student learning process activity that can be viewed from percentage level to student activities in the first phase cycle $83 \%$ which have a fairly active conclusion, and in the next cycle with $100 \%$, (3) there was an increase in the value of student achievement from has an average score of achieved from students in this early cycle 68 with the completeness of student learning in this study by $53 \%$ and in the second cycle 94 with $97 \%$ student learning completeness.
\end{abstract}

Keywords: Improvement, Mathematical Communication, Think Pair Share

(*) Corresponding Author: $\quad$ taufikqurohman87@gmail.com 085642502323

How to Cite: Qurohman, M.T., Romadhon, S.A., \& Sungkar, M.S. (2021). Improvement of mathematical communication skills for students DIII mechanical engineering with think pair share method: A case of Indonesia. Formatif: Jurnal Ilmiah Pendidikan MIPA, $11 \quad$ (2): 233-244. http://dx.doi.org/10.30998/formatif.v11i2.8548

\section{INTRODUCTION}

Indonesian Government through the Directorate of Secondary School Education has built and developed a method development program that connects schools, offices, and universities throughout Indonesia in pandemic era via online. Therefore, the process of data tracking and data monitoring to the related offices can run well, and the process of policy is also quickly implemented. In addition, it is likewise learning process conducted at the level of primary education to higher education that is very relevant to the learning which must always be innovative in its process, and also it is very relevant to use method so that the learning process is expected to be fun and not boring and also can trigger students' achievemen. Based on preliminary observation of DIII Mechanical Engineering students especially Applied Mathematics course 1, it can be seen that the test score was still lower so it became a problem that must be resolved immediately by combining a learning model and science and technology model especially applications that have become a solution to exerts a great influence learning process and outcomes in mathematics lectures. Think Pair Share (TPS) Learning Method is a learning model which has a unique characteristic, which is always started and focused on problems (Arnidha, 2016). In TPS, students can learn with small group capacity groups and must measure what quality they have understood in detail and always try to solve problems (Faradiba et al., 2018). In this learning model, a variety of roles lecturer is to give the 
group the opportunity to processes and processes on learning, and do not provide answers directly. In this research, the learning process is conducted to analyze the level of understanding and problem solving for applied mathematics course 1 by applying Think Pair Share as a model which is integrated with Mathematical Communication. Therefore, this research is expected can provide positive changes to level of achievement and mathematical Troubleshooting especially in the applied mathematics course 1 DIII Mechanical Engineering TPS as one has a unique characteristic that is started and focused on problems (Turyanto et al., 2019).

In research conducted by Chasanah, C (2020) explained that the use of Mathematical Communication can improve cognitive abilities, then subsequent research conducted by Rohid (2019) where this study shows that learning with Mathematical Communication can improve students' solving skills. As well as research conducted by Asih (2019) concludes that learning, especially with mathematical communication, has an influence on the environment with good learning methods. In addition, Suratno (2019) concluded that the priority of learning with mathematics communication that has been built has priority and implementation with an integrated learning system. Then the research conducted by Elihama (2019) saw cooperative learning of the Think Pair Share model in the world of science and technology is a positive influence on the research, especially in the field of science and technology. In TPS, students can work in a limited number of groups and must measure what is known and what they do not know also must have the ability to learn about problem solving. The main role of the lecturer is to facilitate the learning process, they do not provide solutions directly (Rahayu \& Suningsih, 2018). Then TPS as the educational method has the following characteristics: (1)The lecturer by asking questions or problems that have a connection, then asking students to take advantage of a few minutes to think for themselves an answer or problem. Learners need an explanation to speak or perform an action or thought, (2)Furthermore, lecturers ask learners do this learning in pairs and then discuss what they have made. Interactions during the given time may associate answers if a particular problem has been identified. Lecturers give estimated time in this study approximately 5 minutes for this process, and it is done online, (3) In the next step, lecturer asks the couples in this study group are sharing with the whole group they have discussed. Things are generally more effective go around the neighborhood couple to couple and have sustainability some couples get a chance to report (Arnidha, 2016; Faradiba et al., 2018; Hetika et al., 2018; Qurohman, 2018; Rahayu \& Suningsih, 2018). In general, the basic skills that are expected to be explored and improved mathematics learning activities are Mathematical Communication skills. While the indicators on the quality of learners, especially in Mathematics Communication in mathematics learning according to (Nasution \& Ahmad, 2018), can be noted from the : (1) The ability to pour ideas related to mathematics through oral, written, in practice in visually describe them, (2) Ability at the level of understanding is related to what is learned, interpreting it, and evaluating mathematical thinking both verbally and visually, (3) A student's ability to use terms, mathematical signs and their structure to present thoughts, describe correlations and situation (Darkasyi et al., 2014; Hendriana \& Kadarisma, 2019; Nasution \& Ahmad, 2018; Rahmawati, 2013; Umar, 2012). TPS is not only limited for computers and the internet in Covid 19 with Mathematical Communication, but all types of other information and communication media such as radio, audio cassettes, and videos. The integrated TPS learning model is not only seen in the learning activity strategies that are created, both preliminary, core and closing activities, but also in the learning material and learning resources used. 


\section{METHODS}

This research in accordance with CAR standards there are some phases conducted as shown in the figure 1 .

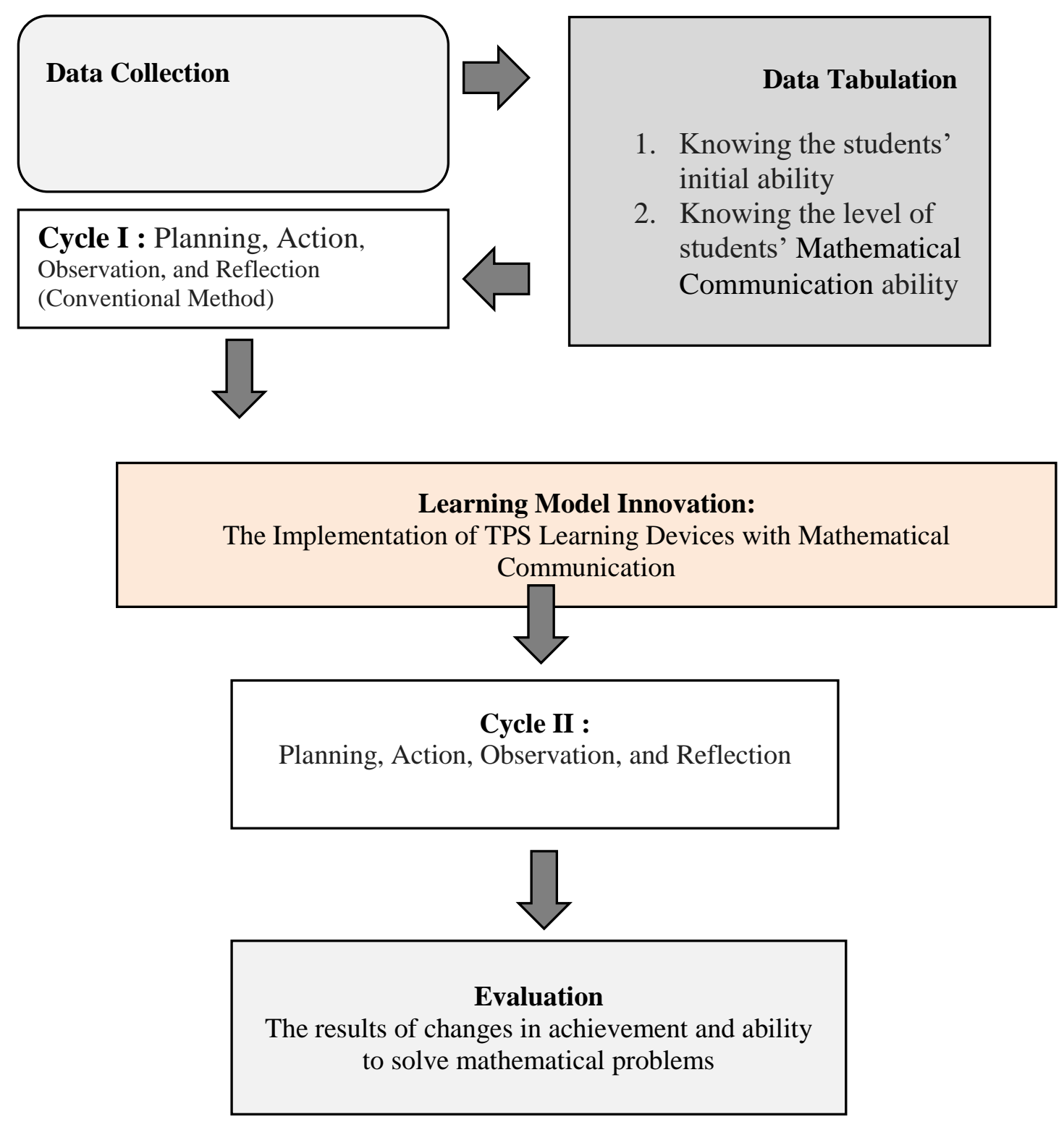

Figure1. Research Phases

Based on Figure 1, the activities of the phases of the research that would be carried out are as follows:

a. Data Collection

Data collection was conducted on the processed data and this phase looked for available data, as well as found additional data needed, then integrated all those data.

b. Data Processing

The initial data was processed the initial ability students and level mathematical problem solving abilities. 
c. Cycle I

The in the teaching and learning process using conventional models through Planning, Action, Observation, and Reflection

d. Learning Model Innovation

e. Cycle II

The implementation of learning model innovation devices.

The learning process by using a means of innovative integrated Think Pair Share and Mathematical Communication, through the process of Planning, Action, Observation, and Reflection.

f. Evaluation

It is the result of a comparison of evaluations between cycle I and cycle II

This research in accordance with CAR standards. This research proposed an innovation model to produce the best model in order to measure the level of achievement and Mathematical Communication abilities. The proposed research design is illustrated in Figure 2.

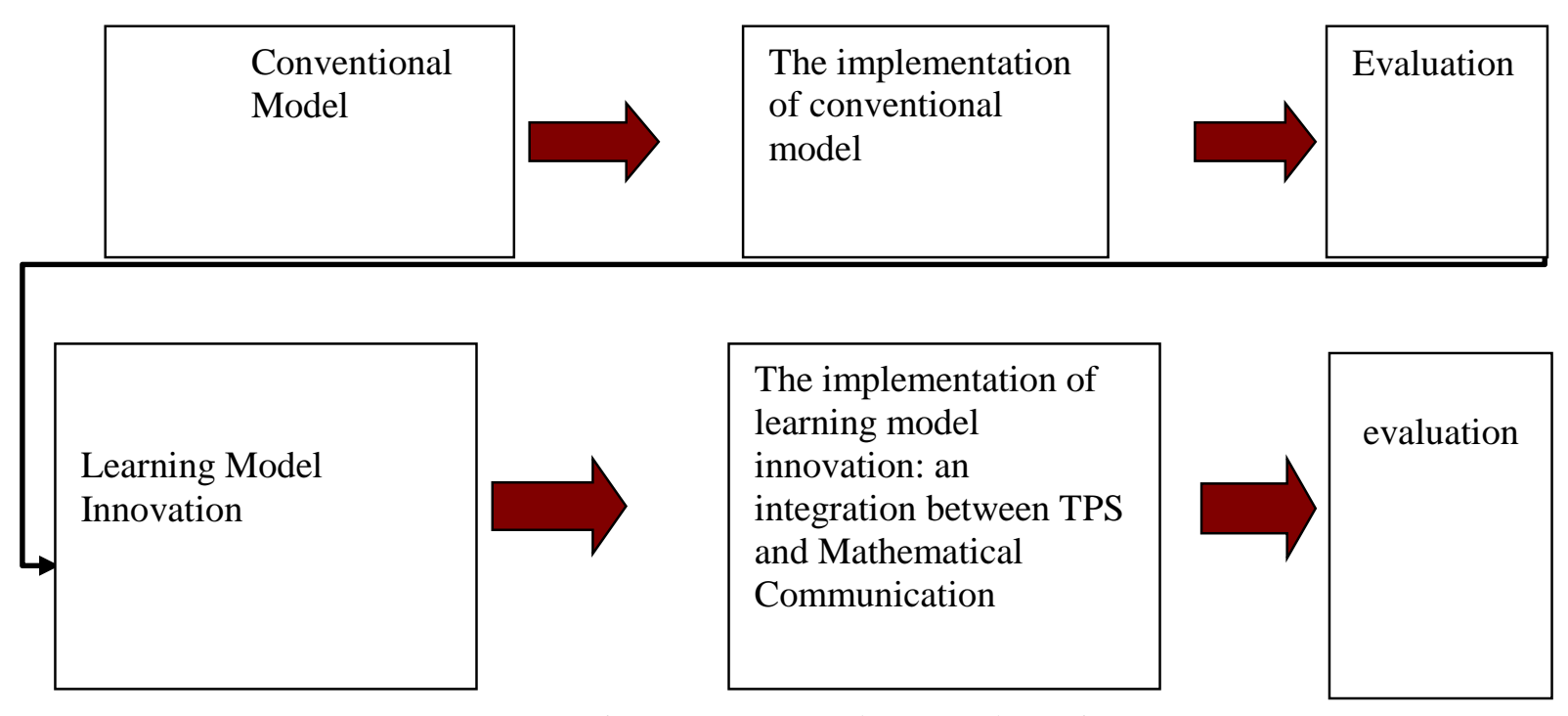

Figure 2. Proposed Research Design

In Figure 2, it is shown that in the implementation of Comparison research by looking at changes in evaluation results from the implemented cycle, can be concluded that the model of innovation is better and vice versa.

g. Data Analysis

The data analysis was presented in a value tabulation and assessment. Quantitatively, average value of obtained data of learning outcomes were calculated, the completeness of their learning was observed, and the percentage of completeness was calculated. It is also same as the results of observation scoring of problem solving abilities, the data obtained were made in tabulation, an assessment was made and the percentage score was calculated. Qualitatively, the results of observations on the implementation of learning were described to give a clear picture. 


\section{RESULTS \& DISCUSSION}

\section{Results}

The experiment was carried out by using the Think Pair Share method that was integrated with Mathematical Communication to get the results of the proposed learning innovation model. The results obtained from the experiments of the learning innovation model are as follows:

a. Cycle I

In order to get the desired learning innovation model, the thing that should be done is to determine the score of student achievement.

\section{1) Planning Activity}

The planning actions in the cycle I were as follows: Making teaching devices in the form of Syllabus (RPS), Lesson plan (RPP), Observation Sheets, and Evaluation tests, Making a coordination other lecturers who act as observers in the learning process, and Conducting an evaluation written test/ an essay to decide ability of students in the applied mathematics course 1 on the material of differential.

\section{2) Implementation Activity}

In the cycle I, the implementation of the learning action has been planned for 7 (seven) meetings for 2x50 minutes and followed by 60 minutes of evaluation. The lecturers' actions are as follows: The lecturer provided apperception and motivation at the beginning of each meeting and reminded the students the things related to the subject that would be taught, The Lecturers gave questions to students in class to find out the students' initial knowledge about applied mathematics courses 1 , then connect with everyday life and guide students to construct it, The students discussed the results of applied mathematical problems in a predetermined group. They explained the plot in turn, provided examples of problems and its solutions, and the other groups responded to it, The students completed and discussed the worksheets given by lecturers, and worked independently. Then the lecturer provided guidance to students if they faced difficulties, The lecturers guided the students to conclude the material that has been obtained at the end of each meeting, At the next meeting the students submitted the results of their discussion and the problem solving of the applied mathematics course 1, and At the end of cycle I an evaluation was conducted to measure and know the ability of students.

\section{3) Observation and Evaluation}

Based on the results of student activeness data tabulation in the learning process, it shows that the improvement is still needed especially in the part of the students' couragement to express opinions, and to link the applied mathematics course material 2 with everyday life. This kind of result occured because there were differences in characteristic abilities among between one and another. The motivation of the lecturer in generating motivation need to be improved again. Furthermore, the overall on a learner's activity in the cycle I was recorded on the observation sheet and later it would be a separate note for the lecturer in making improvements and learning innovations. The evaluation results of the cycle I provide conclusions that the students have not achieved the completeness in the applied mathematics on the differential material yet.

\section{4) Reflection}

Based on the decision evaluation Learners who have no treached the completeness yet in the cycle I, the improvements will be made. Both the learning strategies that need to be 
modified so that there will be learning model innovations through the exercises that students should do. Related to the students' incompleteness in the cycle I, it was found several factors influenced it, such as the students weaknesses in describing the integral questions in the form of differential that must be done in more than one process, as well as the lack of learning media and lecture material books. Therefore, as a form of reflection in thecycleI, the researchers and observers did a coordination and agreed to implement learning media and modules as an effort specifically related to applied form exercises.

Regarding to evaluation and observation results of the treatment given in the cycle I, the cycle II would be conducted in order to improve learning on differential material. The activities in cycle II were as follows: In the introduction (apperception), the lecturer reminded the students the prerequisite material that must be prepared regarding to the questions on the differential material and Having more discussion in groups in which it is expected to increase group levels' improvement and then it increases individual student levels' improvement.

\section{b. Cycle II}

In order to get the desired learning innovation model, the thing that should be done is to determine the score of student achievement.

\section{1) Planning Activity}

The planning activity in the cycle II are as follows : Making teaching devices in the form of Syllabus (RPS), Lesson Plan (RPP), Observation Sheets, and Evaluation Tests, Making a coordination with other lecturers who act as observers in on a learning process, Implementing a learning model by using media with mathematical and web computing software, Conducting evaluation in this study in the form of written tests to determine the ability of students in the applied mathematics on the material of integral.

\section{2) Implementation Activity}

In the cycle II, the implementation of learning actions has been planned for 7 (seven) meetings for $2 \times 50$ minutes and followed by 60 minutes evaluation. The lecturer's actions are as follows: The lecturer provided apperception and motivation at the beginning of each meeting and reminded the students the things related to the subject that would be taught, The Lecturers gave questions to students in class to find out the students' initial knowledge about applied mathematics courses 1 , then connect with everyday life and guide students to construct it, The students discussed the results of applied mathematical problems in a predetermined group. They explained the plot in turn, provided examples of problems and its solutions, and the other groups responded to it, The students completed and discussed the worksheets given by lecturers, and worked independently. Then the lecturer provided guidance to students if they faced difficulties, The lecturers guidedthe students to conclude the material that has been obtained at the end of each meeting, At the next meeting the students submitted the results of their discussion and the problem solving of the applied mathematics course 1, and At the end of cycle II an evaluation was conducted to measure and know the ability of students.

3) Observation and Evaluation

Based on the results of student activeness data tabulation in the learning process, it shows that the improvement is still needed especially in the part of the students' courages to express opinions, and to link the applied mathematics course material 2 with everyday life. This kind of result happened because there are differences in characteristic abilities among students between one and another. The motivation of the lecturer in generating 
motivation needs to be improved again. Furthermore, the overall student activities in the cycle II was recorded on the observation sheet and later it would be a separate note for the lecturer in making improvements and learning innovations. The evaluation results of the cycle II provide conclusions that the students have already achieved the completness in the applied mathematics on the integral material yet.

\section{4) Reflection}

results towards the students in the process of cycle II in which the students achieved completeness, it was seen that there was a modification namely learning model innovation in the form of exercises that the students did, and it could improve students' abilities. Related to the students' completeness in the cycle II, it was also found several factors influenced it including the implementation of Think Pair Share model which is supported by Mathematical Communication that can improve students' ability in describing integral problems which must be done in more than one process. Therefore, as a form of reflection in thecycleII, the researchers and observers did a coordination and agreed to implement learning media and modules as an effort specifically related to applied form exercises.Regarding to evaluation and observation results of the treatment given in the cycle I, the cycle II would be conducted in order to improve learning on differential material. The activities in cycle II were as follows: In the introduction (apperception), the lecturer reminded the students the prerequisite material that must be prepared regarding to the questions on the differential material, Having more discussion in groups in which it is expected to increase group levels' improvement and then it increases individual student levels' improvement, The implementation of media either it make the students easier to solve problems related to integrals, it is also proven can increase student learning motivation, and For the students who are still in the medium category they still get guidance.

\section{Data Analysis}

The results of this study are in the form of qualitativeand quantitative data analysis of students' mathematical communication, activity, and interest.

a. Mathematical Communication

The data got from the conclusion written test in each cycle are as presented in the table 1.

Table 1. Mathematical Communication Analysis

\begin{tabular}{lcc}
\hline Analysis & Cycle & Cycle II \\
& I & \\
\hline Maximum Score & 68 & 94 \\
\hline Minimum Score & 60 & 72 \\
\hline Average & 65 & 77 \\
\hline Number of test taker & 25 & 25 \\
\hline Number of students achieved completeness (passed students) & 16 & 29 \\
\hline Number of students not achieved completeness (unpassed students) & 14 & 1 \\
\hline Percentage of students achieved the completness (passed students) & $53 \%$ & $97 \%$ \\
\hline $\begin{array}{l}\text { Number of students not achieved the completness (unpassed } \\
\text { students) }\end{array}$ & $47 \%$ & $3 \%$ \\
\hline
\end{tabular}




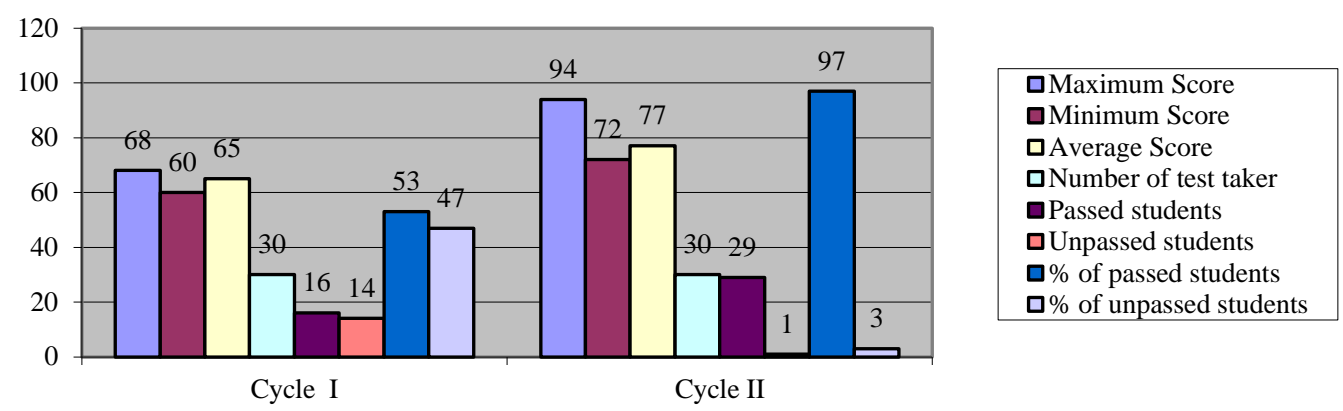

Figure 3. Mathematical Communication Diagram

b. Students' activeness

The results of observation towards the students in each cycle can be viewed in a table 2 .

Table 2. Students' activeness Analysis in Each Cycle

\begin{tabular}{lll}
\hline Analysis & Cycle I & Cycle II \\
\hline Passive & 5 & 0 \\
\hline Quite Active & 18 & 10 \\
\hline Active & 7 & 20 \\
\hline
\end{tabular}

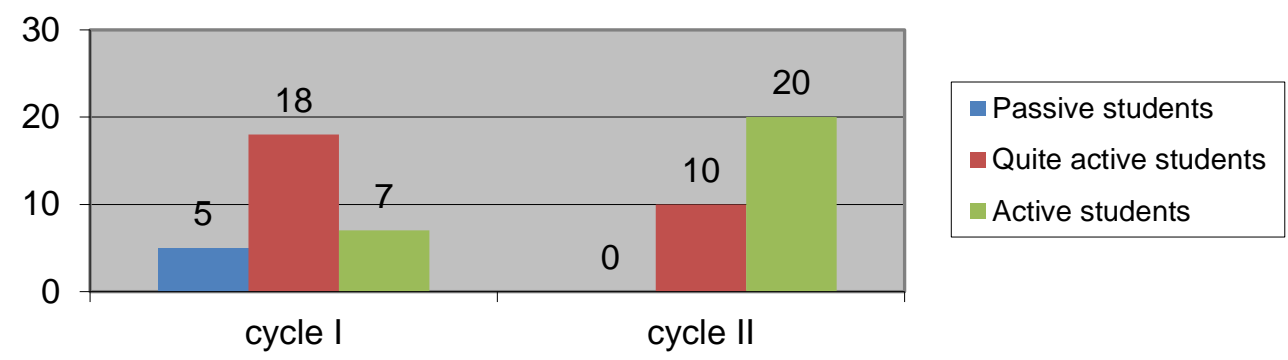

Figure4. Students' Activeness Diagram

c. Students' Interest

The results of questionnaire which was given to the students before they experienced the learning model innovation (an integration between Think Pair Share and Mathematical Communication)and after they experienced it can be seen in the table 3 .

Table 3. Students' Interest Analysis

\begin{tabular}{lll}
\hline Analysis & $\begin{array}{l}\text { Before experiencing } \\
\text { learning model } \\
\text { innovation }\end{array}$ & $\begin{array}{l}\text { After experiencing } \\
\text { learning model } \\
\text { innovation }\end{array}$ \\
\hline Uniterested students & 18 & 0 \\
\hline Interested students & 8 & 26 \\
\hline Very interested students & 4 & 4 \\
\hline
\end{tabular}




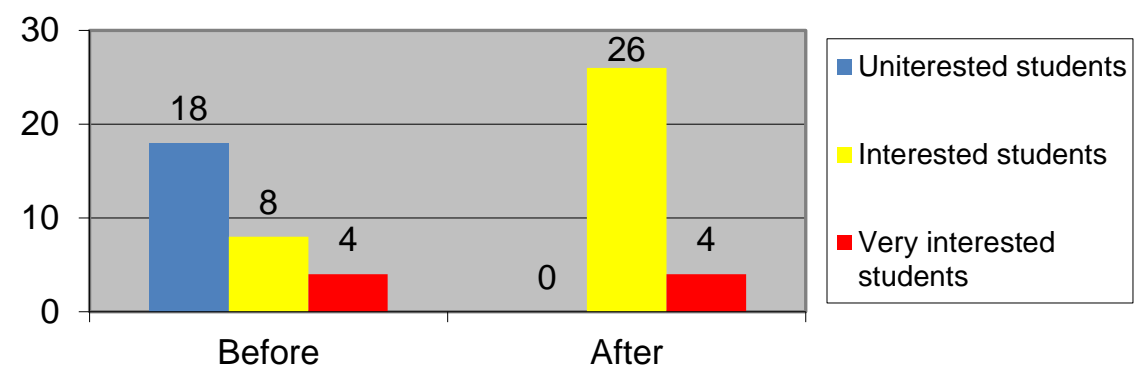

Figure 5. Students’ Interest Diagram

\section{Discussion}

Based on the results of data analysis, it can be got the information that the study results of the students in the second semester of class 1A Mechanical Engineering of Harapan Bersama Polytechnic in the academic year of 2020/2021 after experiencing learning model innovation of Think Pair Share integrated with Mathematical Communication from cycle I up to cycle II are described as follows:

1) Mathematical Communication

The result of data analysis in the cycle I on the differential material in applied mathematics course 1 showed that the average score was 68 with the completeness percentage was $53 \%$. These data were got from the evaluation result. It shows that the determined target has not been achieved yet in which the minimum score should be 70 and the completeness should be $\geq 85 \%$. In addition, the reflection result concludes that there are some difficulties faced by the students in doing evaluation test of differential material in the form of definition, and also in doing the high level of differential test. Therefore, the cycle II was conducted by making a coordination with other lecturers as observers and implementing an innovative learning media in this case Mathematical Communication which was equipped by a dominant computation software and web (Qurohman, 2020; Qurohman \& Bersama, 2017; Romadhon \& Qurohman, 2017, 2019).

In the cycle II after learning process, the students were given worksheets which contained questions about integral material that should be done individually and in group in which it was expected with the increase of students' ability in a group, later it can also increase their own ability. Then, after doing an evaluation in the cycle II, the data showed that the learner scores an average of the students was 94 with completeness percentage was $97 \%$. This result shows that there is an improvement on the learning completness of the students. That was $97 \%$ with the improvement average was $44 \%$.

2) Students' Activeness

There is an improvement on the students' activeness from the cycle I up to cycle II. That is from $83 \%$ on the cycle I to $100 \%$ on the cycle II. This result concludes that the students were more active in the second cycle. Some of the things that are taken into consideration in the process of increasing students' activeness where one of the components is due to the innovation of learning model carried out by researchers, namely the Think Pair Share. By looking at the results of student activeness analysis, this learning model can improve the quality of student activities and facilitate lecturers to empower students, know the differences in student character, and create an active, creative, and fun learning atmosphere (Qurohman et al., 2019).

This learning model also becomes a major factor in creating effective learning. By providing worksheets that lead to the implementation of applied mathematics courses 1 in everyday life is one of the important things in motivating the students to increase their 
curiosity, critical attitude, and awareness in creating learning groups. After getting the worksheets the students got an assingnment in order to construct their understanding related to applied mathematics course 1 on the differential and integral material. Then in the next stage students would try to achieve learning goals, they used experience and knowledge to build dynamic experiences. The ability of lecturers in connecting material with everyday life helps students in understanding the subjects they are studying.

3) Students' Interest

By applying the innovation method of Think Pair Share integrated with Mathematical Communication in the applied mathematics course 1, it can be seen that there was an improvement of students' interest. This improvemnet is due to several factors including motivation, environment, experience, understanding, and factors from the lecturer. Through the implementation of Think Pair Share integrated with Mathematical Communication the students felt that every evaluation and learning experience was very valuable, and they really experienced it themselves. This is in accordance with the main component of learning innovation of Think Pair Share in which the assessment measures all aspects of learning such as: performance, processes, and products done during the learning process and the tasks given to the students by always prioritizing the experience of everyday life that is associated with applied mathematics course 1 .

Based on data analysis, can be observed that results learning process with TPS can be scientifically proven to improve student learning achievement and student learning activities in learning applied mathematics course 1 effectively and it can also increase student learning interest in applied mathematics course 1. In general the improvement of students' achievement in the applied mathematics course 1 was followed by an improvement in students' activities and interests. Therefore, by applying Think Pair Share in applied mathematics course 1, it can invite students to play an active role and involve all abilities possessed by students, so that the understanding of concepts can be well received. Thus, the TPS integrated with mathematical communication can be applied and it is effective to be implemented in applied mathematics course 1.

\section{CONCLUSION}

Based on the results of the research conducted, the conclusion of the implementation of Think Pair Share integrated with in applied mathematics course 1 for second semester students of Politeknik Harapan Bersama in the academic year of 2020/2021 are as follows: Student interest before and after learning undergoes a change in the first cycle that 53\% experienced an increase in $97 \%$ at cycle stage II, There is an increasing for a student learning process activity that can be viewed from percentage level to student activities in the first phase cycle $83 \%$ which have a fairly active conclusion, and in the next cycle with $100 \%$, and In this study there was an increase in the value of student achievement from has an average score of achieved from students in this early cycle 68 with the completeness of student learning in this study by $53 \%$ and in the second cycle 94 with $97 \%$ student learning completeness.

\section{REFERENCES}

Arnidha, Y. (2016). Peningkatan kemampuan representasi matematis melalui model pembelajaran kooperatif Think Pair Share. JURNAL e-DuMath, 2(1). 
Asih, E. C. M. (2019). Creative thinking ability based on learning styles reviewed from mathematical communication skills. Journal of Physics: Conference Series, 1315 (1), p. 012066). IOP Publishing.

Chasanah, C. (2020). The effectiveness of learning models on written mathematical communication skills viewed from students' cognitive styles. European Journal of Educational Research, 9(3), 979-994.

Darkasyi, M., Johar, R., \& Ahmad, A. (2014). Peningkatan kemampuan komunikasi matematis dan motivasi siswa dengan pembelajaran pendekatan quantum learning pada siswa SMP Negeri 5 Lhokseumawe. Jurnal Didaktik Matematika, 1(1).

Elihami, E., Suparman, S., Busa, Y., \& Saharuddin, A. (2019). Pembelajaran Kooperatif Model Think-Pair-Share Dalam Dunia Iptek. Prosiding Seminar Nasional Universitas Cokroaminoto Palopo, 4(1).

Faradiba, S. S., Andriani, P., Alifiani, A., Walida, S. E., Daryono, D., Hasana, S. N., ... \& Qurohman, M. T. (2018). The inconsistency of level critical thinking in solving differential equation problem. International Conference on Mathematics and Science Education of Universitas Pendidikan Indonesia, 3, 842-847.

Hendriana, H., \& Kadarisma, G. (2019). Self-efficacy dan kemampuan komunikasi matematis siswa SMP. JNPM (Jurnal Nasional Pendidikan Matematika), 3(1), 153-164.

Hetika, H., Farida, I., \& Sari, Y. P. (2017). Think pair share (TPS) as method to improve student's learning motivation and learning achievement. Dinamika Pendidikan, 12(2), 125-135.

Nasution, D. P., \& Ahmad, M. (2018). Penerapan pembelajaran matematika realistik untuk meningkatkan kemampuan komunikasi matematis siswa. Mosharafa: Jurnal Pendidikan Matematika, 7(3), 389-400.

Qurohman, M. T. (2018). Think to Talk Write Learning Mathematics Tool Hands on Activity. International Journal of Trends in Mathematics Education Research, 1(3).

Qurohman, M. T. (2017). Analisis perangkat pembelajaran group investigation berbasis rme untuk meningkatkan kemampuan pemecahan masalah materi kalkulus. Prosiding 2nd Seminar Nasional IPTEK Terapan (SENIT) 2017, 2 (1), 156-161.

Arif, S., \& Qurohman, M. T. (2018). Using movie to increase students' vocabulary in Politeknik Harapan Bersama. IJECA (International Journal of Education and Curriculum Application), 1(2), 104-108.

Rahayu, S., \& Suningsih, A. (2018). The effects of type learning model numbered head together and think pair share. International Journal of Trends in Mathematics Education Research, 1(1), 19-21.

Rahmawati, F. (2013). Pengaruh pendekatan pendidikan realistik matematika dalam meningkatkan kemampuan komunikasi matematis siswa sekolah dasar. Prosiding SEMIRATA 2013, 1(1).

Rohid, N. (2019). Students' mathematical communication skills (MCS) in solving mathematics problems: A case in Indonesian context. Anatolian Journal of Education, 4(2), 19-30.

Romadhon, S. A., \& Qurohman, M. T. (2017). The advantages of youtube to enhance student's vocabulary in mechanical engineering classroom. Wiralodra English Journal, 1(1), 14-20.

Romadhon, S. A., \& Qurohman, M. T. (2019). Increasing mechanical engineering students' speaking skills using guided conversation. EnJourMe (English Journal of Merdeka): Culture, Language, and Teaching of English, 4(1), 18-24. 
Suratno, J., Tonra, W. S., \& Ardiana. (2019). The effect of guided discovery learning on students' mathematical communication skill. AIP Conference Proceedings, 2194 (1), 020119.

Sumekto, D. R. (2018). Investigating the influence of think-pair-share approach toward students' reading achievement. Lingua Cultura, 12(2), 195-202.

Turyanto, T., Agustito, D., \& Widodo, S. A. (2019). Think pair share with comic for mathematical problem solving skills. Formatif: Jurnal Ilmiah Pendidikan MIPA, 9(3).

Umar, W. (2012). Membangun kemampuan komunikasi matematis dalam pembelajaran matematika. Infinity Journal, 1(1), 1-9. 